Thabiea : Journal of Natural Science Teaching
Program Studi Tadris Ilmu Pengetahuan Alam
Institut Agama Islam Negeri Kudus
http://journal.stainkudus.ac.id/index.php/Thabiea
p-issn: $2580-8974$, e-issn: $2655-898 x$

\title{
Pemanfaatan Alat dan Bahan dari Lingkungan sebagai Media Pembelajaran Sederhana Mata Pelajaran IPA untuk Meningkatkan Motivasi Belajar Siswa MTs Muwahidun Gembong
}

\author{
Dody Rahayu Prasetyo ${ }^{a, 1^{*}}$, Ulya Fawaida ${ }^{b, 2}$, Faiq Makhdum Noor ${ }^{c, 3}$ \\ a,b,c IAIN Kudus, Jalan Conge Ngembalrejo No.51, Ngembal Rejo, Kabupaten Kudus, Jawa Tengah 59322 \\ 1'dody@iainkudus.ac.id*; ${ }^{2}$ ufawaida@yahoo.com; ${ }^{3}$ faiq@iainkudus.ac.id
}

\begin{tabular}{ll}
\hline & ABSTRAK \\
\hline Kata kunci: & Penelitian ini bertujuan untuk mendesain dan menghasilkan media pembelajaran \\
Media Pembelajaran & sederhana mata pelajaran IPA menggunakan alat dan bahan dari lingkungan \\
Sederhana; & sekitar, serta meningkatkan motivasi siswa MTs Muwahidun. Metode \\
Mata Pelajaran IPA; & pengumpulan data pada penilitian ini ada empat, yaitu: 1) studi pustaka, 2) \\
Lingkungan Sekitar & observasi, 3) wawancara, dan 4) angket. Model 4D digunakan dalam \\
Motivasi; & pengembangan penelitian ini yang terdiri atas tahapan: 1) Difine, 2) Design, 3) \\
& Develop, 4) Disseminate. Hasil penelitian yang diperoleh yaitu: 1) media \\
& pembelajaran yang dikembangkan layak untuk digunakan dalam pembelajaran dan \\
& 2) dengan menggunakan media pembelajaran, motivasi siswa meningkat. Hal ini \\
& didasarkan dari 1) media pembelajaran dinyatakan layak oleh ahli, 2)ketersediaan \\
& alat dan bahan dalam pembuatan media pembelajaran sangat memadai, 3) media \\
& pembelajaran yang dibuat bersifat konkret sesuai dengan umur siswa MTs dan \\
& sesuai dengan KI-KD pada kurikulum 2013, dan 4) media pembelajaran menarik \\
dan mudah dipahami.
\end{tabular}

Keyword:
Simple Learning Media;
Natural Sciences;
Surrounding environment
Motivation;

ABSTRACT

Utilization of Tools and Materials from the Environment as a Simple Learning Media for Science Subjects to Improve Student Motivation in MTs Muwahidun Gembong. This study aims to design and produce simple learning media for science subjects using tools and materials from the surrounding environment, as well as to increase the motivation of students at MTs Muwahidun. There are four data collection methods in this research, namely: 1) literature study, 2) observation, 3) interview, and 4) questionnaire. The 4D model was used in the development of this study which consisted of 4 stages, there are: 1) Difine, 2) Design, 3) Develop, 4) Disseminate. The results obtained are: 1) learning media developed are suitable for use in learning and 2) by using learning media, student motivation increases. This is based on 1) learning media deemed appropriate by experts, 2) the availability of tools and materials in making instructional media very adequate, 3 ) learning media are made to be concrete in accordance with the age of MTs students and in accordance with KI-KD in the 2013 curriculum, and 4) learning media is interesting and easy to be understand.

Copyright $\odot 2019$ Institut Agama Islam Negeri Kudus. All Right Reserved

\section{Pendahuluan}

Pembelajaran IPA merupakan pembelajaran yang menuntut untuk membuktikan sesuatu antara teori dan fakta melalui eksperimen (Widhy, 2009). Dalam kehidupan sehari-hari kita bisa mengamati melalui kejadian alam yang terjadi. Misalnya proses gerhana bulan, proses terjadinya pelangi dan lain-lain. Pembelajar IPA akan lebih bermakna jika kita mampu menemukan sesuatu hal baru yang akan menjadikan pengalaman baru dank an merangsang kita untuk berfikir kritis. Salah satunya adalah dengan cara pembuktian, di sekolah biasanya siswa ada kegiatan praktikum untuk membuktikan suatu 
teori sehingga siswa bisa berfikir secara relevan antara fakta dan teori.

Selain kegiatan praktikum proses pembelajaran siswa akan menarik jika ada media pembelajaran di dalam kelas sehingga proses pembelajaran bisa berjalan dengan maksimal. Hal ini karena media pembelajaran adalah alat menyampaikan pesan atau sumber belajar IPA kepada siswa sehingga terjadi lingkungan belajar yang kondusif (Dudo et al., 2018). Namun ada beberapa kendala yang menyebabkan siswa tidak bisa menikmati pembelajaran bermakna tersebut, diantaranya: Pertama, banyak madrasah yang belum memiliki media pembelajaran. Media pembelajaran merupakan salah satu penunjang keberhasilan pembelajaran dalam menigkatkan minat dan atensi siswa (Taiwo, 2009). Selain itu, media yang digunakan berasal dari bahan yang murah dan mudah diperoleh dan guru dapat dengan mudah membuatnya (Kemendikbud, 2017). Namun, masih jarang madrasah-madrasah yang memiliki media tersebut karena berbagai alasan. Kedua, Guru merasa kerepotan apabila melakukan peragaan sederhana dalam kelas karena membutuhkan waktu yang lebih banyak. Karena kita tahu untuk menggunakan media diperlukan waktu tambahan, selain itu guru tidak ada yang membantu didalam kelas sehingga tidak banyak guru yang malam menggunakan media yang rumit dan butuh waktu lama untu menyusunnya. Ketiga, siswa kurang tertarik dengan media pembelajaran yang sulit dipahami dalam pembelajaran karena alat dan bahan yang digunakan tidak dikenal oleh siswa. Oleh karena itu, penting dilakukan penelitian tentang pemanfaatan alat dan bahan dari lingkungan sekitar sebagai media pembelajaran sederhana pada mata pelajaran IPA untuk meningkatkan motivasi belajar siswa.

\section{Metode}

Penelitian ini termasuk penelitian $R \& D$ dengan menggunakan model 4D sebagai pendekatannya. Subyek di dalam penelitian ini adalah 95 siswa kelas VII, 89 siswa kelas VIII, dan 80 siswa kelas IX MTs Muwahidun. Tahapan dalam penelitian ini antara lain sebagai berikut. Model pengembangan 4-D terdiri dari empat tahap utama yakni: Define (Pendefinisian), Design (Perancangan), Develop (Pengembangan), Disseminate (Penyebaran). Adapun langkah-langkahnya ditampilkan sebagai berikut:

1. Define (Pendefinisian) terdiri atas: a) analisis peserta didik bertujuan untuk mengetahui karakteristik peserta didik, b) analisis tugas bertujuan untuk mengidentifikasi kompetensi apa saja yang harus dikuasai oleh peserta didik, c) analisis konsep dilakukan untuk mengidentifikasi konsep pokok dari materi yang akan diajarkan. Analisis yang dilakukan mencakup analisis terhadap KIKD materi IPA tingkat SMP, d) Spesifikasi tujuan pembelajaran disusun berdasarkan hasil analisis konsep dan analisis tugas, dan e) analisis motivasi dilakukan untuk mengetahui motivasi belajar siswa dengan pembelajaran sebelumnya.

2. Design (Perancangan) terdiri atas: a) Pemilihan format dalam pengembangan media pembelajaran ini mengacu pada materi pelajaran, pemilihan strategi, serta sumber belajar yang digunakan, b) Pada tahap rancangan awal diperoleh draf I media pembelajaran IPA sederhana. Hasil dari rancangan awal ini berupa draf I yang akan divalidasi oleh ahli berdasar kriteriakriteria sebagai berikut (Sudjana dan Rivai, 2011): a) ketepatannya dengan tujuan pembelajaran, b) dukungan terhadap isi pembelajaran, c) kemudahan memperoleh media, d) keterampilan guru dalam menggunakanya, e) tersedianya waktu untuk menggunakannya, dan f) sesuai dengan taraf berfikir peserta didik.

3. Develop (Pengembangan)

Tahap pengembangan bertujuan untuk menghasilkan pedoman penggunaan media pembelajaran IPA sederhana yang sudah direvisi berdasarkan hasil uji coba. Langkah yang dilakukan pada tahap ini 
adalah sebagai berikut: a) Validasi Ahli. Draf I atau produk awal yang telah disusun kemudian divalidasi oleh para ahli serta diberi tanggapan oleh guru IPA (Agus Sujatmiko, S.Pd, Nur Istiqomah, S.Pd, dan Suyati, S.Pd) dan teman sejawat (Andi Asyhari, M.Pd. dan Henry Setya Budhi, M.Pd) untuk memperoleh kritik dan saran. Validasi yang dilakukan oleh para ahli diperoleh dari ahli materi, media, dan penilaian. Tanggapan dari guru diperoleh dari guru IPA di sekolah tersebut sedangkan tanggapan dari teman sejawat diperoleh dari teman seprofesi. Berdasarkan hasil tersebut, kemudian dilakukan revisi I sehingga menghasilkan draf II. b) Uji Coba Terbatas. Draf II yang telah diperoleh kemudian diujicobakan secara terbatas yang bertujuan untuk melihat sejauh mana keterlaksanaan pembelajaran di kelas. Proses uji coba terbatas diamati dengan menggunakan lembar keterlaksanaan pembelajaran yang mengacu pada RPP yang telah disusun. Berdasarkan uji coba terbatas kemudian dilakukan revisi II sehingga menghasilkan draf III. c) Uji Coba Luas. Uji coba lebih luas bertujuan untuk mengetahui keefektifan hasil pengembangandraf III berupa media pembelajaran IPA sederhana. Uji coba luas menggunakan subjek yang lebih banyak dari uji coba terbatas. Hasil dari uji coba luas terhadap draf III ini kemudian direvisi dan akan menjadi produk akhir media pembelajaran IPA sederhana. Disamping itu juga dilakukan analisis motivasi setelah pembelajaran. Indikator penilaian motivasi dalam penelitian ini yaitu: a) Hasrat dan keinginan untuk berhasil, b) Dorongan dan kebutuhan untuk belajar, c) Harapan dan cita-cita masa depan, d) Penghargaan dalam belajar, e) Kegiatan yang menaarik dalam belajar, dan f) Lingkungan belajar yang kondusif.

\section{Disseminate (Penyebaran)}

Pada tahap ini, Disseminate (Penyebaran) dilakukan dengan cara mempublish hasil pengembangan produk media pembelajaran IPA sederhana melalui jurnal yang telah terkadreditasi.

\section{Hasil dan Pembahasan}

Studi pendahuluan yang dilakukan adalah dengan mencari media pembelajaran sederhana terkait KI-KD mata pelajaran IPA kelas VII, VIII, dan IX MTs. Hasil analisis ditampilkan pada Tabel 1.

Tabel 1. Analisis KD dan praktikum

\section{Kelas VII}

KI 3.3 dan KD 4.3

Judul Praktikum:

- Pemisahan Zat Warna

Alat dan Bahan:

- (1) kertas saring (2) spidol warna merah dan hijau (3) pensil (4) air

KI 3.4 dan KD 4.4

Judul Praktikum:

- Pemuaian pada Udara

Alat dan Bahan:

- (1) Botol plastik kemasan, (2) Balon, (3) Mangkok/wadah air, (4) Air

KI 3.4 dan KD 4.4

Judul Praktikum:

- Membakar gelas kemasan plastik berisi air Alat dan Bahan:

- (1) Gelas kemasan plastik, (2) Air, (3) Lilin/korek api

KI 3.5 dan KD 4.5

Judul Praktikum:

- Pertumbuhan kecambah

Alat dan Bahan:

- (1) Biji kacang hijau (2) kapas (3) kardus berbentuk kubus (4) air

KI 3.5 dan KD 4.5

Judul Praktikum:

- Perubahan energi panas menjadi energi gerak Alat dan Bahan:

- (1) Lilin satu buah (2) Korek api (3) Kertas

(4) Benang $1 \mathrm{~m}$ (5) Gunting

KI 3.8 dan KD 4.8

Judul Praktikum: 
- Penyaringan sederhana

Alat dan Bahan:

- (1) botol aqua besar yang dipotong pangkalnya (2) kerikil bersih (3) serabur kelapa yang sudah dibersihkan (3) arang katu yang sudah bersih (4) kapas (5) pewarna merah yang sudah dilarutkan di air (6) gelas aqua

\section{Kelas VIII}

KI 3.2 dan KD 4.2

Judul Praktikum:

- Pengaruh gaya terhadap gerak

Alat dan Bahan:

- (1) Kertas (2) Gelas berisi air

KI 3.2 dan KD 4.2

Judul Praktikum:

- $\quad$ Tes Kekuatan Tulang

Alat dan Bahan:

- (1) cuka (2) gelas plastic (3) tulanng ayam

KI 3.8 dan KD 4.8

Judul Praktikum:

- Gaya Apung

Alat dan Bahan:

- (1) Botol plastik 1 atau 2 liter, (2) Air secukupnya, (3) Tutup pulpen yang diberikan gantungan pemberat

KI 3.8 dan KD 4.8

Judul Praktikum:

- Daya Kapilaritas pada Batang

Alat dan Bahan:

- (1) Tumbuhan pacar air (2) gelas berisi air (3) pewarna merah

KI 3.9 dan KD 4.9

Judul Praktikum:

- Kandungan $\mathrm{CO}_{2}$ dan $\mathrm{H}_{2} \mathrm{O}$ dalam Pernapasan Alat dan Bahan:

- (1) Dua buah gelas, (2) Sendok/pengaduk,

(3) Cermin/kaca, (4) Kapur/gamping, (5) Sedotan, (6) Air

\section{Kelas IX}

KD 3.4 dan 4.4

Judul Praktikum:

- $\quad$ Listrik Statis

Alat dan Bahan:

- (1) Dua buah sedotan plastik (2) Tissue (3) Benang

KD 3.6 dan 4.6

Judul Praktikum:

- Induksi Elektromagnetik
Alat dan Bahan:

- (1) Batu baterai (2) Kawat tembaga (3) Paku (4) Jarum

KD 3.5 dan 4.5

Judul Praktikum:

- Membuktikan Adanya Boraks pada Makanan Alat dan Bahan:

- Pisau, Sample bakso, Pipet tetes, Air kunyit, Mie, Kerupuk dan Boraks

Alat dan bahan pada kegiatan praktikum yang tersaji pada Tabel 1, ketersediaannya sangat memadai melihat lokasi MTs Muwahidun berada di dekat pusat pemerintahan kecamatan Gembong Pati. Pasar dan toko berada di pusat kecamatan Gembong. Setelah mendesain kegiatan praktikum tersebut, dibuat lembar kerja siswa yang nantinya akan divalidasi oleh validator guru IPA dan teman sejawat berdasarkan aspek penilaian diantaranya: a) analisis peserta didik, b) analisis tugas, c) analisis konsep, dan d) Spesifikasi tujuan pembelajaran. Hasil validasi dsajikan pada Tabel 2 .

Tabel 2. Hasil Validasi Media Pembelajaran

\begin{tabular}{|c|c|c|c|}
\hline \multirow{2}{*}{ No } & \multirow{2}{*}{ Validator } & \multicolumn{2}{|c|}{ Penilaian } \\
\hline & & $\%$ & Kriteria \\
\hline 1. & $\begin{array}{l}\text { Andi } \\
\text { Asyhari, } \\
\text { M.Pd }\end{array}$ & $90 \%$ & $\begin{array}{c}\text { Layak } \\
\text { digunakan tanpa } \\
\text { revisi }\end{array}$ \\
\hline 2. & $\begin{array}{l}\text { Henry } \\
\text { Setya } \\
\text { Budhi, } \\
\text { M.Pd }\end{array}$ & $92 \%$ & $\begin{array}{c}\text { Layak } \\
\text { digunakan tanpa } \\
\text { revisi }\end{array}$ \\
\hline 3. & $\begin{array}{l}\text { Agus } \\
\text { Sujatmiko, } \\
\text { S.Pd. }\end{array}$ & $91 \%$ & $\begin{array}{c}\text { Layak } \\
\text { digunakan tanpa } \\
\text { revisi }\end{array}$ \\
\hline 4. & $\begin{array}{l}\text { Nur } \\
\text { Istiqomah, } \\
\text { S.Pd }\end{array}$ & $93 \%$ & $\begin{array}{c}\text { Layak } \\
\text { digunakan tanpa } \\
\text { revisi }\end{array}$ \\
\hline 5. & $\begin{array}{l}\text { Suyati, } \\
\text { S.Pd. }\end{array}$ & $95 \%$ & $\begin{array}{c}\text { Layak } \\
\text { digunakan tanpa } \\
\text { revisi }\end{array}$ \\
\hline
\end{tabular}

Berdasarkan Tabel 2, media pembelajaran layak untuk digunakan di dalam pembelajaran. Jika dilihat dari karakterisktik siswa MTs/SMP kegiatan pembelajaran sains 
bersifat konkret bukan bersifat abstrak (Sidharta \& Winduono, 2012). Selain itu media pembelajaran yang dibuat disesuaikan dengan KI-KD di dalam kurikulum 2013, ditunjukkan Tabel 1. Konsep yang dibuktikan melalui media pembelajaran, dapat dengan mudah dipahami siswa karena mengacu pada kompetensi yang dicapai siswa. Selanjutnya, dilakukan uji skala terbatas dan luas berdasarkan indikator sebagai berikut: a) keterampilan siswa dalam mempersiapkan, b) keterampilan menggunakan media, dan c) lama penggunaan media. Uji skala terbatas dilakukan di MTs Mujahidin kelas IX berjumlah 9 orang dapat dilihat pada Gambar 1.

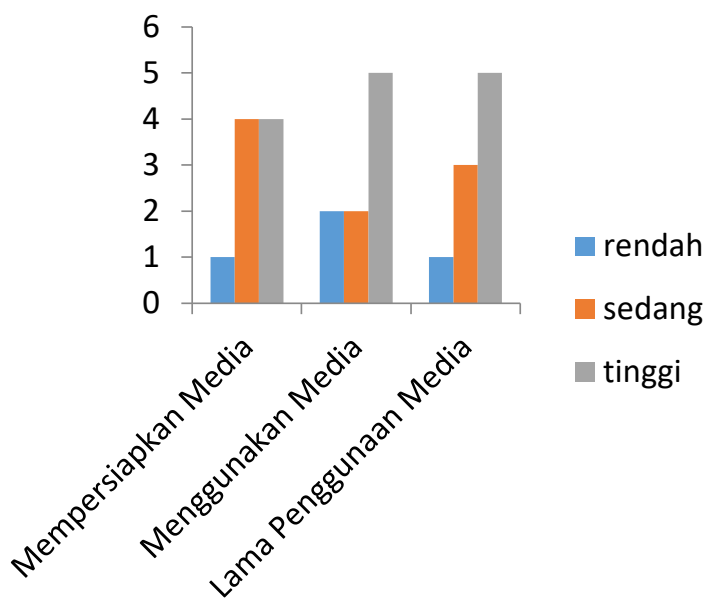

Gambar 1. Hasil Uji Skala Terbatas

Berdasarkan Gambar 1, jika dilihat dari pencapaian indikator, siswa sebagian besar mencapai kemampuan tinggi saat menggunakan media pembelajaran. Hal ini berarti media pembelajaran sudah siap untuk diuji skala luas. Selanjutnya, uji skala luas dilakukan pada kelas VII, VIII, dan IX sesuai dengan media yang telah dibuat. Dari hasil uji skala luas siswa dapat dikelompokkan berdasarkan kemampuan yang dicapainya. Pengelompokan siswa berdasarkan kemampuan yang dicapai, yaitu: kemampuan tinggi, sedang, dan rendah. Hal ini mengadobsi dari hasil penelitian Prasetyo (2018), bahwa di dalam kelas siswa dapat dibagi kemampuannya berdasarkan pemahamannya. Hasil pengelompokkan siswa dapat dilihat pada Gambar 2a-c.

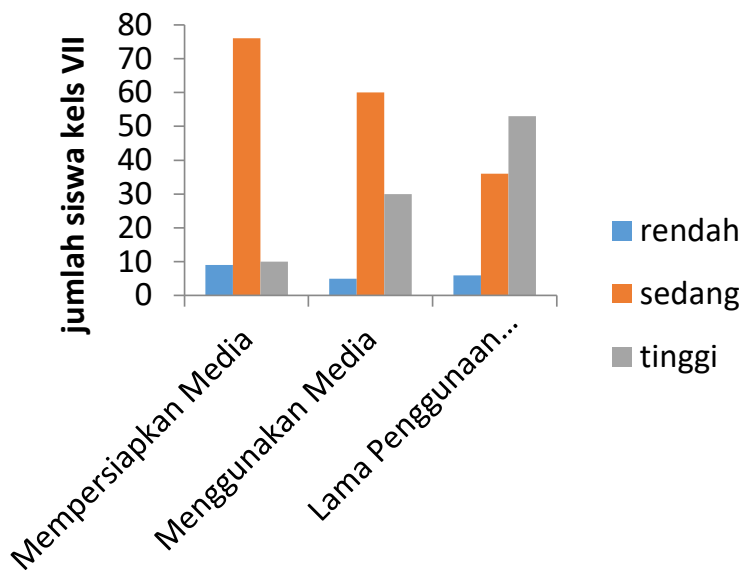

Gambar 2a. Hasil Uji Skala Luas Kelas VII

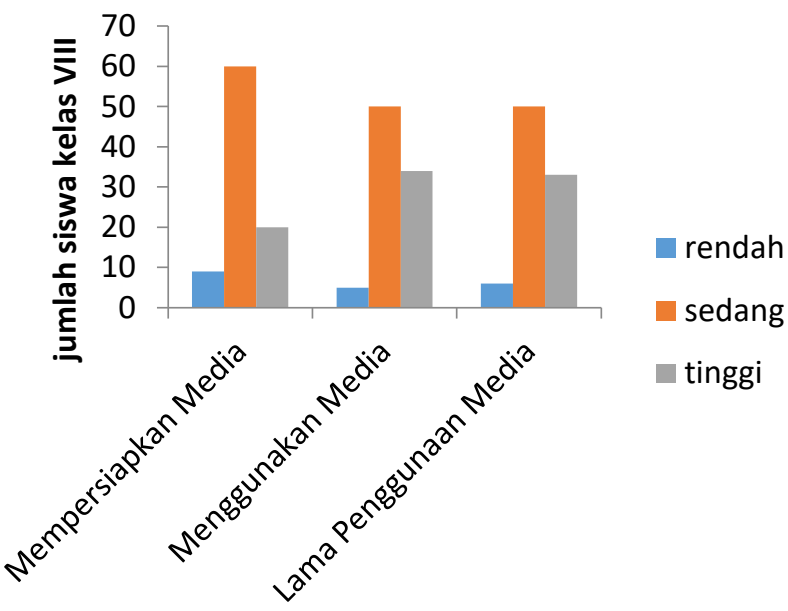

Gambar 2b. Hasil Uji Skala Luas Kelas VIII

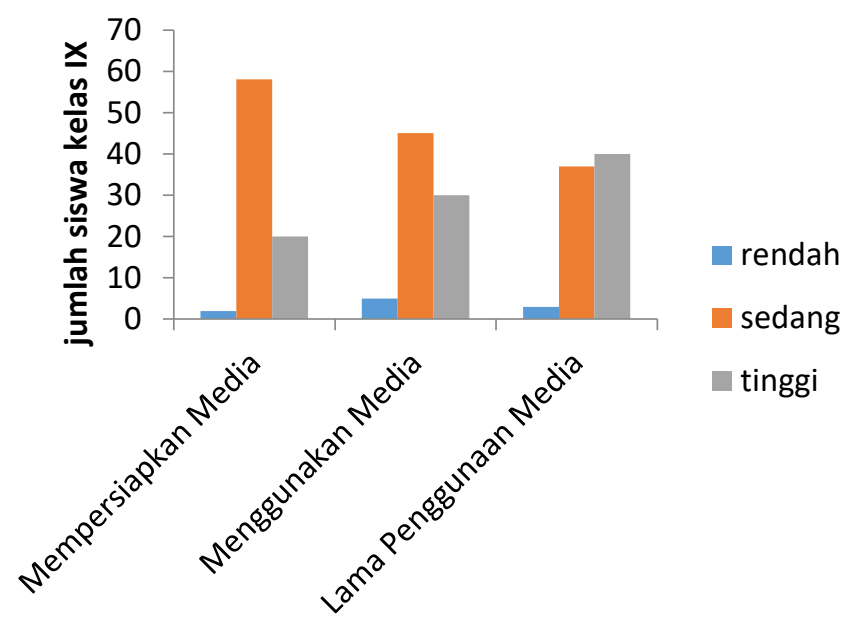

Gambar 2c. Hasil Uji Skala Luas Kelas IX 
Berdasarkan Gambar 2a-c, dapat disimpulkan bahwa siswa yang dengan kemampuan sedang mendominasi kelas pada indikator mempersiapkan media. Hal ini terjadi karena sebagian besar mereka mengenal dan mengetahui fungsi dari alat dan bahan di sekitar mereka. Siswa yang memiliki kemampuan rendah dipengaruhi oleh belum mengenal semua alat dan bahan yang digunakan dan juga fungsinya, sehingga mereka mengalami kesulitan. Untuk siswa yang memiliki kemampuan tinggi, dipengaruhi oleh beberapa faktor: mereka telah mengenal alat dan bahan dan ketertarikkannya dalam sains. Hal ini juga dibuktikan dari hasil wawancara guru IPA, bahwa siswa dengan kemampuan tinggi tersebut lebih aktif dibandingkan siswa yang lain. Pada indikator menggunakan media, siswa dengan kemampuan sedang lebih mendominasi. Hal ini disebabkan karena petunjuk dalam praktikum dapat dipahami dengan mudah, meskipun ada yang tidak dipahami. Siswa yang memiliki kemampuan rendah, cenderung kesulitan dalam memahami dan menerapkan petunjuk di dalam praktikum. Siswa yang memiliki kemampuan tinggi, tidak mengalami masalah dalam memahami dan menerapkan petunjuk di dalam praktikum.

Pada indikator lama penggunaan media, siswa kelas VII dan IX yang mendominasi adalah siswa yang memiliki kemampuan sedang dibandingkan yang lain, tetapi kelas VIII justru yang mendominasi adalah siswa dengan kemampuan tinggi. Hal ini disebabkan kelas VII dan IX banyak mengalami kesalahan dalam memahami petunjuk praktikum, sehingga mereka harus mengulang beberapa tahapan dalam praktikum. Secara garis besar, siswa dalam kelompok mampu melaksanakan praktikum sesuai dengan waktu yang telah ditentukan. Hal ini sejalan dengan Dudo et al. (2018), bahwa ada respon setelah menggunakan media pembelajaran yang terbuat dari bahan bekas.

Peningkatan motivasi belajar siswa yang terlihat setelah menggunakan media pembelajaran di indikator penghargaan dalam kelas, kegiatan yang menarik dalam belajar, dan lingkungan belajar yang kondusif dan ditampilkan pada Gambar 3a-c.

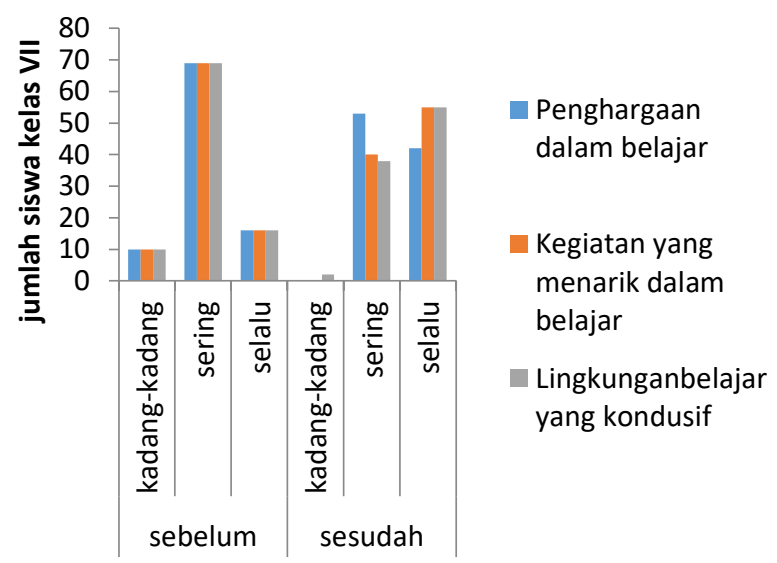

Gambar 3a. Peningkatan Motivasi Belajar pada Kelas VII

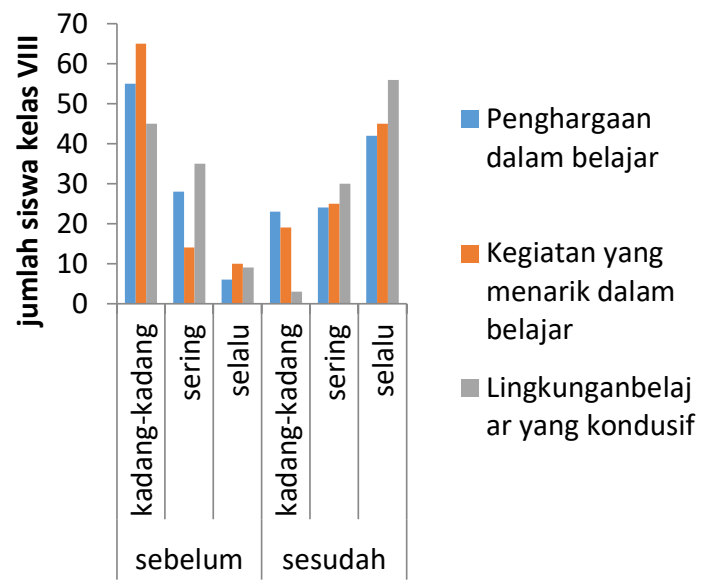

Gambar 3b. Peningkatan Motivasi Belajar pada Kelas VIII

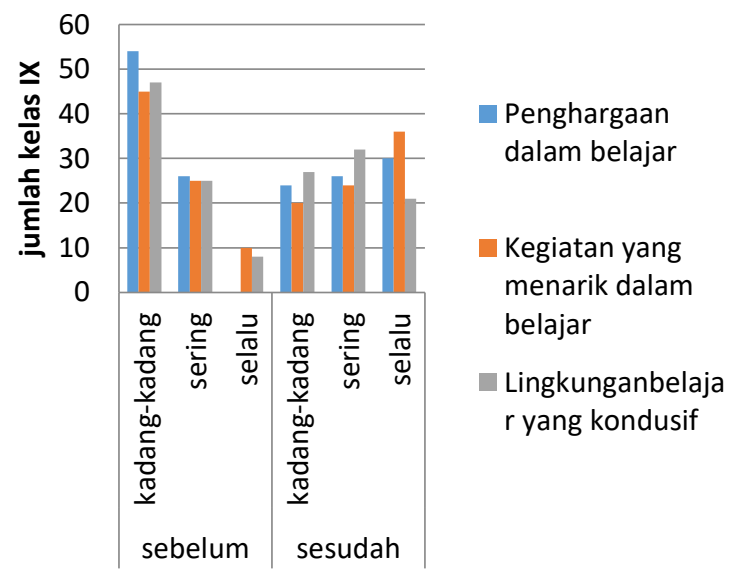

Gambar 3c. Peningkatan Motivasi Belajar pada Kelas IX 
Berdasarkan Gambar 3a-c, setelah menggunakan media pembelajaran, siswa lebih termotivasi, jika dibandingkan dengan sebelum menggunakan media. Hal ini terlihat dari berkurangnya siswa yang mengisi "kadangkadang" pada tiap indikator. Hal ini sejalan dengan yang ditemukan oleh Taiwo (2009), bahwa minat dan atensi siswa meningkat setelah menggunakan media pembelajaran.

\section{Simpulan}

Hasil penelitian yang diperoleh yaitu: 1) media pembelajaran yang dikembangkan layak untuk digunakan dalam pembelajaran dan 2) dengan menggunakan media pembelajaran, motivasi siswa meningkat. Hal ini didukung oleh beberapa faktor: 1) ketersediaan alat dan bahan dalam pembuatan media pembelajaran sangat memadai, 2) media pembelajaran yang dibuat bersifat konkret sesuai dengan umur siswa MTs dan sesuai dengan KI-KD pada kurikulum 2013, dan 3) media pembelajaran menarik dan mudah dipahami.

\section{Referensi}

Prasetyo, D.R. 2018. Tingkat Pemahaman Konsep Siswa pada Materi Momen Gaya. Thabiea Journal of Natural Science Teaching. Vol 1, No. 2.

Dudo, H.J., Awang, I.S., \& Andri. 2018. PKM Pelatihan Pemanfaatan Bahan Bekas sebagai Media Pembelajaran IPA bagi Kelompok Guru IPA. Jurnal Pengabdian kepada Masyarakat, Vol.8(1) Juli 2018.

Kemendikbud. 2017. Panduan Pengembangan Media Pembelajaran Sederhana. Jakarta

Sidharta, A \& Widuono, Y. 2012. Pengembangan Alat Peraga Praktik (APP) Sederhana untuk Guru SMP. Jakarta: P4TK IPA untuk Program Bermutu.

Sudjana, N., dan Rivai, A. 2011. Media Pengajaran. Bandung. Sinar Baru Algensindo.

Taiwo, S. 2009. Teachers' Perception of The Role of Media in Classroom Teaching in Secondary School. The Turkish Online of Journal of Educational Technology volume 8 Issue 1 Article 8.

Widhy, Purwanti. 2009. Alat dan Bahan Kimia dalam Laboratorium IPA. Makalah disampaikan pada Pelatihan Penggunaan Alat Laboratorium IPA tanggal 21-22 Februari 2009 di SMP N 3 Gamping Sleman Yogyakarta. 